Al-Manhaj: Jurnal Hukum dan Pranata Sosial Islam

Vol. : : 3 (2), 2021, 244-267

P-ISSN : 2686-1607

E-ISSN : 2686-4819

\title{
PRAKTIK AKAD NIKAH BAGI MEMPELAI TUNAWICARA DALAM PERSPEKTIF KOMPILASI HUKUM ISLAM
}

\author{
Achmad Baihaqi, Said Abadi
}

Institut Agama Islam Negeri Ponorogo

email: achmadbaihaqi.iain@gmail.com, abadi@iainponorogo.ac.id

Abstract: The author is interested in researching the practice of the marriage contract with the bride and groom who have limitations in pronouncing the contract (impaired), from practice in the field it is often the case that the marriage contract of the non-verbal bride is carried out by a representative but without a clear power of attorney, it is not entirely wrong. Because sometimes both parties believe that there will be no dispute in the appointment of representatives. The bride and groom base the implementation of their marriage contract on the encouragement of the community, clerics, customs, and indeed an agreement between the two parties. The approach method used in this paper is a juridical-normative approach in the study of fiqh. A juridical approach by examining legal rules and a normative approach in the study of fiqh is used in analyzing problems that occur in society. For provisions that require the granting of power in writing, basically it is not stipulated in the book of fiqh. In fact, fiqh explicitly stipulates that it can be in the form of words (a) (عبـ or in written form. There is nothing wrong with the provisions stipulated by the Compilation of Islamic Law, which are promulgated, following the rules of al-maslahah al-mursalah which have been explained or the concept in the book of Bughyah al-Mustarsyidn which says that government decrees which are not forbidden by the Shari'a must be obeyed physically and mentally. If it is against the Shari'a, such as obliging something that is haram, then it is enough to obey outwardly. 
In article 17 paragraph (3) of the KHI which reads "For the prospective bride and groom who suffers from speech impairment or deafness, consent can be stated in writing or signs that can be understood," so without a power of attorney there is nothing wrong or allowed. What is clear is that the marriage is still valid, the KUA does not require the speech-impaired bride and groom to make or show a power of attorney.

Keywords: Compilation of Islamic Law, Marriage, Blind Speech

Abstrak: Penulis tertarik meneliti praktik aqad nikah dengan mempelai yang mempunyai keterbatasan dalam mengucapkan aqad (tunawicara), dari praktek di lapangan sering terjadi akad nikah mempelai tunawicara yang dilaksanakan oleh wakil namun tanpa adanya surat kuasa yang jelas, tidak sepenuhnya salah. Karena adakalanya kedua belah pihak yakin akan tidak adanya perselisihan dalam penunjukan wakil. Para mempelai melandaskan pelaksanaan akad nikah mereka pada dorongan masyarakat, kiyai, adat, dan memang kesepakatan antara kedua belah pihak. Metode pendekatan yang digunakan dalam penulisan ini adalah dengan pendekatan yuridis - normative dalam kajian fiqh. Pendekatan yurirdis dengan mengkaji aturan-aturan hukum dan pendekatan normative dalam kajian fikih digunakan dalam menganalsis permasalahan yang terjadi di masyarakat. Untuk ketetapan yang mewajibkan pemberian kuasa berbentuk tulisan, pada dasarnya tidak ditetapkan dalam kitab fiqh. Malah fiqh secara tegas menetapkan ia boleh berbentuk kata-kata (عبارة) atau berbentuk tulisan. ketetapan yang ditetapkan Kompilasi Hukum Islam ini tidak ada salahnya diundang-undangkan, mengikut kaidah al-maslahah al- mursalah yang telah dijelaskan atau konsep dalam kitab Bughyah al-Mustarsyidîn yang mengatakan bahwa ketetapan pemerintah yang tidak diharamkan secara syariat wajib ditaati secara lahir dan batin. Kalau ia bertentangan dengan syariat seperti mewajibkan sesuatu yang haram, maka cukup taat secara lahir saja. Dalam pasal 17 ayat (3) KHI yang berbunyi "Bagi calon mempelai yang menderita tunawicara atau tunarungu persetujuan dapat dinyatakan dengan tulisan atau isyarat yang dapat dimengerti" maka tanpa surat kuasapun tidak mengapa atau diperbolehkan. Yang jelas adalah nikahnya tetap sah, pihak KUA tidak menuntut para mempelai tunawicara untuk membuat atau menunjukan surat kuasa. 
Kata Kunci: Kompilasi Hukum Islam, Nikah, Tunawicara

\section{PENDAHULUAN}

Nikah (zawaj), jika diruju' menurut Bahasa bisa diartikan dengan aqdu l-tazwij atau akad nikah, bahkan ada ulama yang mengartikan sebagai wath'u al-zaujah atau menyetubuh istri. Rahmat Hakim berpendapat bahwa nikah merupakan kata serapan dari Bahasa Arab "nikahun" yang merupakan asal kata (Masdar) dari "nakaha" (fi'il madhi). Nakaha ini sama artinya dengan tazawwaja yang diartikan dalam Bahasa Indonesia menjadi "perkawinan". Lambat laun kata "nikah"- nya yang malah lebih familiar. ${ }^{1}$ Slamet Abidin dan Aminuddin memberi definisi yang lebih umum. Pernikahan merupakan sunnatullah atau hokum alam dan berlaku kepada semua makhluk-Nya baik hewan, tumbuhan, dan manusia. Pernikahan ini adalah cara yang digunakan oleh Allah agar makhluk-Nya bisa berkembang biak dan meneruskan generasi. $^{2}$

Umat Islam harus meyakini bahwa pernikahan merupakan perjanjian syari'at aqad syar'I yang sah atau batalnya semata-mata ditentukan oleh hukum Illahi. Hal ini dinyatakan sebagai sebuah perjanjian yang sangat kuat dan kokoh, sebagaimana disebut dalam Al-Qur"an dengan ungkapan ikatan yang kokoh, yang mana perjanjian itu bukan hanya sekedar disaksikan oleh dua orang saksi yang ditentukan atau orang banyak yang hadir pada saat

\footnotetext{
${ }^{1}$ Hakim Rahmat, Hukum Perkawinan Islam (Bandung: Pustaka Setia, 2000), p. hlm.11.

2 M. Karman Supiana, Materi Pendidikan Agama Islam, cet. Ke-3 (Bandung: Remaja Rosdakarya, 2004), p. hlm. 125.
} 
berlangsungnya akad perkawinan, tetapi juga disaksikan oleh Allah SWT. Sebagaima disebutkan dalam surat an-Nisa' ayat 21, Allah telah berfirman :

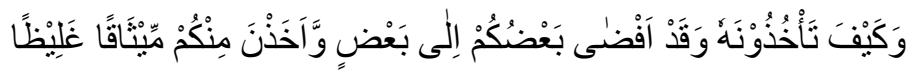

"Dan bagaimana kamu akan mengambilnya kembali (pemberian itu) padahal sebagian kamu telah bergaul dengan sebagian yang lain (sebagai suami istri) dan mereka telah mengambil dari padamu janji yang teguh?" (Q.S an-Nisa'[4]: 21) 3

Pasal 1 Undang-Undang Nomor 1 Tahun 1974 Tentang Perkawinan menyebutkan bahwa "Pernikahan merupakan ikatan lahir batin antara seorang pria dengan seorang wanita sebagai suami istri dengan tujuan membentuk keluarga yang bahagia dan kekal berdasarkan Ketuhanan Yang Maha Esa”.4

Dalam pasal 3 KHI dinyatakan bahwa "Perkawinan bertujuan untuk mewujudkan kehidupan rumahtangga yang sakinah (tentram), mawaddah (penuh cinta) dan rahmah (penuh kasih sayang).5 Pasal tersebut mengacu pada Q.S. ar-Rum ayat 21:

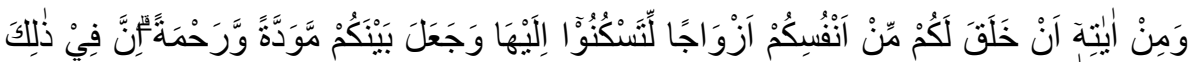

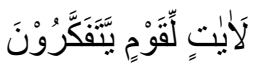

Artinya :"Dan di antara tanda-tanda kekuasaan-Nya ialah Dia menciptakan untukmu isteri-isteri dari jenismu sendiri, supaya kamu cenderung dan merasa tenteram kepadanya, dan dijadikan- Nya diantaramu rasa kasih dan sayang. Sesungguhnya pada yang 
demikian itu benar benar terdapat tanda-tanda bagi kaum yang berfikir." (Q.S al-Rum: 21).4

Dari firman Allah tersebut dapat disimpulkan bahwa dalam suatu perkawinan itu terkandung unsur ketentraman dalam rumah tangga sebagai sumber kebahagiaan dan ketentraman yang dijalani dengan rasa mawaddah yaitu rasa kasih sayang diantara suami istri. Ada yang menafsirkan mawaddah itu nafsu birahi yang dilengkapi lagi dengan rahmah, yaitu kasih sayang mengikat kedua suami isteri. Guna mencapai sakinah harus disertai cinta birahi dan kasih sayang. ${ }^{5}$

Hidup berkeluarga menurut Islam harus diawali dengan pernikahan. Perkawinan menurut Islam yaitu akad yang sangat kuat atau mithaqan ghalizan untuk mentaati perintah Allah dan melaksanakanya merupakan ibadah. Mithaqan ghalizan merupakan perjanjian yang membingkai suami istri secara khusus dan keluarga secara umum. ${ }^{6}$

Dalam pernikahan ridlonya laki-laki dan perempuan serta persetujuan antara keduanya merupakan hal yang pokok untuk mengikat hidup berkeluarga. Perasaan ridlo dan setuju bersifat kejiwaan yang tidak dapat dengan jelas, karena itu harus ada perlambang yang tegas untuk menunjukkan kemauan mengadakan ikatan bersuami istri. Perlambang itu diutarakan dengan kata-kata p. hlm. 34 .

${ }^{4}$ Mahalli A. Mudjab, Menikahlah Engkau Menjadi Kaya (Yogyakarta: Mitra Pustaka, 2008),

${ }^{5}$ Idhamy Dahlan, Azas Fiqh Munakahat (Surabaya: Al Ikhlas, 1984), p. hlm.11.

${ }^{6}$ Shahrur Muhammad, Metodologi Fiqh Islam Kontemporer, Cet V, ((Yogyakarta: Elsa Press, 2008), p. hlm.32. 
oleh kedua belah pihak yang melangsungkan akad. Inilah yang merupakan sighat dalam pernikahan.

Dalam melaksanakan ijab dan qabul para ulama' fiqh sependapat bahwa dalam qabul boleh digunakan kata-kata dengan bahasa apapun, tidak terikat satu bahasa atau dengan kata-kata khusus asalkan menunjukkan rasa ridla dan setuju, misalyan "saya terima, saya setuju, saya laksanakan" dan sebagainya. ${ }^{7}$ Pasangan serasi itu terlihat bukan dari kekayaannya yang sama, juga bukan sama-sama tampan dan cantik, Namun pasangan serasi adalah pasangan yang memiliki pola pikir dan pola sikap Islam, artinya sama-sama berkepribadian Islam. ${ }^{8}$

semua akad itu sah untuk diwakilkan kecuali ibadah seperti solat. Sedangkan ketetapan harus pemberian kuasa tersebut berbentuk tulisan, pada dasarnya tidak ditetapkan dalam fiqh. Malah fiqh secara perbandingan secara tegas menetapkan ia boleh berbentuk kata-kata (عبارة) atau berbentuk tulisan. Juga tidak ditetapkan harus ada saksi (dalam proses mewakilkan). ${ }^{9}$

Manusia sebagai makhluk Tuhan yang paling mulia karena dianugerahi akal dan pikiran, adakalanya dilahirkan tidak sempurna secara fisik. Berkurangnya atau hilangnya sebagian fungsi fisik bisa dialami sejak lahir maupun sebab lain. Setiap anak yang lahir di dunia adalah anugerah terindah dari Tuhan Yang Maha Esa kepada setiap orang tua. Adapun setiap anak terlahir dengan

${ }^{7}$ Sohari Sahrani Tihami, Fikih Munakahat: Kajian Fikih Nikah Lengkap (Jakarta: Rajawali, 2010), p. hlm. 80.

${ }^{8}$ Ridha Salamah Abu Zaid, Membangun Rumah Tangga Ideologis (Jakarta: PT. Wahyu Media Pertiwi, 2003), p. hlm. 40.

${ }^{9}$ al-Khathîb Muhammad al-Syirbînî, Mughnî Al-Muhtâj, vol. 4, (Beirut: Dâr al-Kutub al'Ilmiyyah, t.t), p. hlm. 241. 
sempurna ataupun terlahir secara istimewa memerlukan perhatian dan pelayanan khusus dari orang tua maupun lingkungan sekitar. Salah satu anak luar biasa atau istimewa itu adalah anak tunawicara. Tunawicara adalah suatu kerusakan atau gangguan dari suara, artikulasi dari bunyi bicara, dan atau kelancaran berbicara. ${ }^{10}$

Hal tersebut dilakukan karena untuk mempermudah pemahaman terhadap apa yang diisyaratkan oleh mempelai pria ketika pengucapan qabul. Sedangkan jika ditinjau dari Kompilasi Hukum Islam pengucapan qabul harus diucapkan secara pribadi oleh mempelai pria (pasal 29 ayat 1). Selain itu pasal 29 ayat 2 juga mewajibkan jika terjadi pewakilan maka harus ada surat kuasa yang jelas secara tertulis, namun sudah menjadi kesepakatan bersama di antara keduanya, sedangkan calon pengantin suami istri ini hadir.

\section{Definisi Kompilasi Hukum Islam}

Pengertian Kompilasi Hukum Islam secara etimologis ialah kumpulan/himpunan yang tersusun secara teratur. Sedangkan secara terminologi kompilasi diambil dari compilation (inggris) atau compilatie (belanda) yang diambil dari kata compilare, artinya mengumpulkan bersama-sama, seperti mengumpulkan peraturanperaturan yang tersebar dimana-mana, istilah ini kemudian 
dipergunakan dalam bahasa Indonesia kompilasi, sebagai terjemahan langsung.

Sekumpulan materi hukum Islam yang ditulis pasal demi pasal, berjumlah 229 pasal, terdiri atas kelompok materi hukum yaitu hukum perkawinan, (170 pasal) hukum kewarisan termasuk wasiat dan hiba (44 pasal) dan hukum perwakafan (14 pasal) ditambah satu pasal ketentuan penutup yang berlaku untuk ketiga kelompok hukum tersebut. Kompilasi Hukum Islam disusun melalui proses yang sangat panjang dan melelahkan karena pengaruh perubahan social politik terjadi di negeri ini dari masa ke masa. ${ }^{11}$

Jadi dari pendapat Abdurrahman tersebut kita dapat menyimpulkan bahwa Abdurrahman menyimpulkan bahwa kompilasi adalah suatu kegiatan pengumpulan dari berbagai bahan yang tertulis yang diambil dari berbagai buku maupun tulisan mengenai suatu persolan tertentu. Pengumpulan bahan dari berbagai sumber yang dibuat oleh beberapa sumber yang berbeda untuk ditulis dalam suatu buku tertentu, sehinggadari kegiatan itu semua bahan yang diperlukan akan dapat ditemukan dengan lebih mudah.

\section{Perkawinan dan Seputar Penjelasannya}

Perkawinan adalah sunnatullah, hukum alam di dunia. Perkawinan dilakukan oleh manusia, hewan, bahkan oleh tumbuhtumbuhan. Allah swt. berfirman dalam surah Yasin ayat 36, yang berbunyi: 12

11 Abdurrahman, Kompilasi Hukum Islam Di Indonesia, ((Jakarta : Akademika Pressindo, 1992), p. hlm. 11.

12 H. Said Al Hamdani, Hukum Perkawinan Islam, (Jakarta: Pustaka Amani, 2002), p. hlm. 1. 


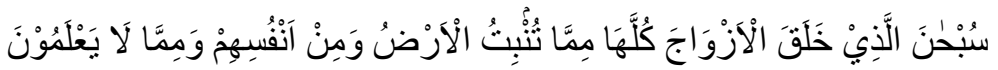

Artinya: Maha Suci Allah yang telah menjadikan pasanganpasangan semuanya, baik dari apa yang ditumbuhkan di bumi dan dari diri mereka maupun dari apa yang tidak mereka ketahui. (Q.S. Yasin: 36)

Dalam surah Adz-Dzariyat ayat 49, Allah berfirman :

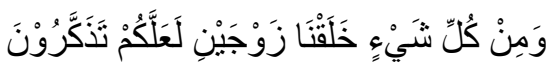

Artinya: Dan segala sesuatu Kami ciptakan berpasangpasangan supaya kamu mengingat kebesaran Allah. (Q.S. AdzDzariyat: 49).

Inilah yang dinamakan "law of sex" atau "hukum berpasangan" yang telah diletakkan oleh Maha Pencipta bagi segala sesuatu. Dengan demikian perkawinan atau berpasangan merupakan sunatullah, dalam artian ketetapan Tuhan yang diberlakukannya terhadap semua makhluk. ${ }^{13}$

Perkawinan merupakan suatu cara yang dipilih oleh Allah sebagai jalan bagi manusia untuk beranak, berkembang biak dan menjaga kelestarian hidupnya, setelah masing-masing pasangan siap melakukan peranannya yang positif dalam mewujudkan tujuan perkawinan. Dalam hal ini menunjukkan bahwa, Tuhan tidak menjadikan manusia seperti makhluk lainnya,yang hidup bebas mengikuti nalurinya, dan berhubungan antara jantan dan betina secara bebas tanpa aturan. Akan tetapi demi menjaga kehormatan dan martabat, Allah membuat hukum sesuai dengan martabatnya. ${ }^{14}$

\footnotetext{
${ }^{13}$ M. Quraish Shihab, Pengantin Al-Qur'an, ((Jakarta: Lentera Hati, 2007), p. hlm. 1. 2011), p. hlm. 21.

${ }_{14}$ Abdul Ghofur Anshori, Hukum Perkawinan Islam, ((Yogyakarta: UII Press Yogyakarta,
} 
Dengan demikian antara laki-laki dan perempuan diatur dengan syariat Islam secara terhormat dan berdasarkan saling meridhai dengan diadakannya ijab qabul dan dihadiri wali dan para saksi sebagai lambing adanya kesepakatan dari kedua mempelai. Sedangkan dalam UU No. 1 tahun 1974 pada pasal 1, disebutkan bahwa, perkawinan ialah ikatan lahir bathin antara seorang pria dan seorang wanita sebagai suami istri dengan tujuan membentuk keluarga (rumah tangga) yang bahagia dan kekal berdasarkan Ketuhanan Yang Maha Esa. ${ }^{15}$

Dalam hubungan ini, Prof. R. Sardjono SH, mengatakan bahwa "ikatan lahir" berarti para pihak yang bersangkutan karena perkawinan itu secara formil merupakan suami istri baik bagi mereka dalam hubungannya satu sama lain maupun bagi mereka dalam hubungannya dengan masyarakat luas. Kemudian, "ikatan bathin" dalam perkawinan berarti bahwa dalam bathin suami istri yang bersangkutan terkandung niat yang sungguh-sungguh untuk hidup bersama sebagai suami istri dengan tujuan membentuk dan membina keluarga bahagia dan kekal.

Dalam Kompilasi Hukum Islam (KHI) pada pasal 2 disebutkan bahwa, perkawinan menurut hukum Islam adalah pernikahan, yaitu akad yang sangat kuat atau mitsaqqan ghalidzan untuk menaati perintah Allah dan melaksanakannya merupakan ibadah. ${ }^{16}$

Dengan demikian dapat disimpulkan bahwa perkawinan adalah suatu ikatan yang sah antara seorang laki-laki dan seorang

${ }^{15}$ Asmin SH., Status Perkawinan Antar Agama, ((Jakarta: Dian Rakyat, tt),), p. hlm. 19.

${ }^{16}$ Abdurrahman,. 
perempuan untuk membentuk sebuah keluarga yang sakinah, mawaddah, dan warahmah serta sebagai bentuk mentaati aturan yang telah ditetapkan oleh Allah Swt.

\section{Tujuan Perkawinan}

Mengenai tujuan perkawinan menurut UU No. 1/1974 pda pasal 1 dengan tujuan membentuk keluarga (rumah tangga) yang bahagia dan kekal berdasarkan Ketuhanan Yang Maha Esa. Pada pasal tersebut mengandung harapan, bahwa dengan melangsungkan perkawinan akan diperoleh suatu kebahagiaan, baik materiil maupun spirituil. Pandangan ini sejalan dengan sifat religius dari bangsa Indonesia yang mendapatkan realisasinya di dalam kehidupan beragama dan bernegara. ${ }^{17}$

Telah diketahui bahwa, perkawinan dalam Islam memiliki tujuan dan kemaslahatan bagi masyarakat, yaitu antara lain: ${ }^{18}$

a. Memelihara spesies manusia

Dengan menikah, kelangsungan keturunan manusia tetap berlanjut, terus bertambah, dan berantai untuk mewarisi dunia dan seisinya. Semakin banyak dan semakin turun-temurunnya manusia merupakan pemeliharaan terhadap spesies manusia.

b. Memelihara keturunan (nasab)

Pernikahan atau perkawinan yang sesuai dengan syariat Allah akan membuat anak-anaknya bangga terhadap orang

18 Abdul Wahab Al-Sayyid Hawwas, Kunikahi Engkau Secara Islami, ((Bandung: Pustaka Setia, 2007), p. hlm. 29. 
tuanya. Karena kemungkinan, tali keturunan (nasab) itu melahirkan penghargaan yang sebenarnya, keteguhan jiwa, dan kemuliaan sifat anak-anak. Sebaliknya, apabila pernikahan tidak sesuai dengan syariat Allah, bisa jadi anak akan tidak memiliki kehormatan dan kemuliaan di mata masyarakat. Menyelamatkan manusia dari kemorosotan akhlak Pernikahan akan menyelamatkan masyarakat dari kemorosotan akhlak dan mengamankan anggota masyarakat dari disintegrasi. Setiap orang yang memiliki pengetahuan dan pemahaman menyadari bahwa naluri atau tabiat manusia terkadang cenderung pada seks dan perselingkuhan, padahal dia telah kenyang dengan pernikahan yang baik dan hubungan yang halal, maka pengetahuan dan pemahaman tentang pernikahan akan menghiasi anggota masyarakat dengan adab yang baik dan akhlak yang baik. Dengan demikian, pernikahan atau perkawinan akan menjadi menarik dengan melaksanakan risalah, membawa tanggung jawab ke arah yang diinginkan oleh Allah Swt.

c. Menyelamatkan manusia dari penyakit

Pernikahan atau perkawinan akan menyelamatkan masyarakat dari penyakit menular. Penyakit mematikan yang menyebar di antara anggota masyarakat merupakan akibat dari hasil zina dan hubungan yang haram. Penyakit-penyakit yang kotor dan penyakit lainnya yang berbahaya akan merusak keturunan manusia dan membuat badan menjadi lemah. Hal ini disebabkan karena melakukan hubungan (seks) bebas. ${ }^{19}$ 
Sedangkan dalam Kompilasi Hukum Islam (KHI), tujuan dari perkawinan adalah untuk mewujudkan kehidupan rumah tangga yang sakinah, mawaddah, dan warahmah.43 Kemudian menurut ilmu kedokteran, tujuan perkawinan yaitu menjaga keturunan, mengeluarkan cairan (mani) yang berbahaya kalau ditahan, dan bersenang-senang.

d. Rukun dan Syarat Sah Perkawinan

1) Rukun Perkawinan

Rukun yaitu sesuatu yang pasti dan menentukan sah dan tidaknya suatu pekerjaan (ibadah), dan sesuatu itu termasuk dalam rangkaian pekerjaan itu, seperti membasuh muka untuk wudhu atau takbiratul ihram untuk ibadah shalat. Atau juga adanya calon pengantin laki-laki/perempuan dalam perkawinan.45 Jadi dapat diketahui bahwa, rukun merupakan suatu hal pokok dalam sebuah pekerjaan (ibadah), apabila salah satu rukun tidak terpenuhi, maka perbuatan (ibadah) tersebut tidak akan sah.

Dalam Kompilasi Hukum Islam, disebutkan terkait rukun perkawinan yang terdapat pada pasal 14. Untuk melaksanakan perkawinan maka harus ada: calon suami, calon istri, wali nikah, dua orang saksi, dan ijab dan qabul. ${ }^{20}$

Sedangkan mengenai rukun perkawinan menurut jumhur ulama sepakat bahwa rukunnya terdiri atas:

a) Adanya calon suami

${ }^{20}$ Ghofur Anshori, p. hlm. 31. 
Dalam hal ini, calon mempelai laki-laki tidak boleh ada hubungan saudara atau mahram dengan calon istri, kemudian tidak sedang dalam keadaan terpaksa, orangnya jelas, dan tidak sedang melakukan ihram. ${ }^{21}$

b) Adanya Calon Istri

Sama dengan calon suami, calon mempelai perempuan pun juga tidak boleh adanya hubungan mahram dengan calon mempelai laki-laki, dan tidak juga sedang melakukan ihram.

c) Adanya wali dari pihak calon mempelai perempuan

Akad perkawinan atau pernikahan akan dianggap sah apabila ada seorang wali atau wakilnya yang akan menikahkannya. Berdasarkan sabda Nabi Saw. yang berbunyi: "perempuan mana saja yang menikah tanpa seizing walinya, maka pernikahannya batal, pernikahannya batal, pernikahannya batal. (HR. semua Muhadditsin kecuali Imam Nasa'i)

Wali bagi mempelai perempuan ini terbagi menjadi dua yaitu wali dekat (qarib) dan wali jauh ( $a b^{\prime} a d$ ). Seseorang boleh menjadi wali apabila ia merdeka, berakal, dewasa, dan harus beragama Islam. Sebab apabila walinya tidak beragama Islam, maka tidak boleh menjadi wali nikahnya orang Islam. ${ }^{22}$

d) Adanya Dua Orang Saksi

${ }^{21}$ Alhamdani, Risalah Hukum Perkawinan Islam, ((Jakarta: Citra Karsa Mandiri, 1995), p. hlm.83.

${ }^{22}$ Slamet Abidin dan Aminuddin, Fiqh Munakahat Juz 1, ((Bandung: Pustaka Setia, 1999), p. 
Pelaksanaan akad nikah akan sah apabila ada dua orang saksi yang menyaksikan akad nikah tersebut. Dalam Kompilasi Hukum Islam (KHI) yang dapat ditunjuk sebagai saksi dalam akad nikah ialah seorang laki-laki muslim, adil, aqil, baligh, tidak terganggu ingatan dan tidak tuna rungu atau tuli.

e) Sighot Aqad Nikah

Yaitu ijab qabul yang diucapkan oleh wali atau wakilnya dari pihak calon mempelai perempuan, dan dijawab oleh calon mempelai laki-laki. ${ }^{23}$ Dalam Kompilasi Hukum Islam (KHI) yang terdapat pada pasal 27 disebutkan bahwa "ijab dan kabul antara wali dan calon mempelai pria harus jelas beruntun dan tidak berselang waktu".

Dalam Kompilasi Hukum Islam (KHI) pada pasal 29

disebutkan bahwa akad nikah dilaksanakan sendiri secara pribadi oleh wali nikah yang bersangkutan. Selain itu yang berhak mengucapkan kabul ialah calon mempelai pria secara pribadi. Dalam hal-hal tertentu ucapan kabul nikah dapat diwakilkan kepada pria lain dengan ketentuan calon mempelai pria memberi kuasa yang tegas secara tertulis bahwa penerimaan wakil atas akad nikah itu adalah untuk mempelai pria. Kemudian pada ayat ke 3, disebutkan bahwa dalam hal calon mempelai wanita atau wali keberatan calon

${ }^{23}$ Ghofur Anshori, p. hlm. 31. 
mempelai pria diwakilkan, maka akad nikah tidak boleh dilangsungkan. ${ }^{24}$

Namun demikian walaupun rukun-rukun perkawinan semuanya terpenuhi, maka agar memiliki kekuatan di mata hukum hendaknya pada saat perkawinan disaksikan oleh Pegawai Pencatat Nikah (PPN) dari Kantor Urusan Agama (KUA) setempat sesuai dengan Undang Undang (UU) perkawinan yang berlaku di Indonesia.

2) Syarat Sah Perkawinan

Syarat yaitu sesuatu yang mesti ada yang menentukan sah atau tidaknya suatu pekerjaan (ibadah), tetapi sesuatu itu tidak termasuk dalam rangkaian pekerjaan itu, seperti menutup aurat untuk ibadah shalat. Atau menurut Islam, calon pengantin laki-laki atau perempuan itu harus beragama Islam. Sedangkan sah yaitu sesuatu pekerjaan (ibadah) yang memenuhi rukun dan syarat. ${ }^{25}$

Secara garis besar syarat-syarat sahnya suatu perkawinan itu dibagi menjadi dua, yaitu sebagai berikut: 26

a) Calon mempelai perempuannya halal dikawin oleh laki-laki yang ingin menjadikannya istri. Jadi, perempuannya itu bukan merupakan orang yang haram dinikahi, baik karena haram untuk sementara maupun selama-lamanya.

b) Akad nikahnya dihadiri para saksi. Saksi yang menghadiri akad nikah haruslah dua orang laki-laki yang muslim,

${ }^{24}$ Abdurrahman,.

25 Ghofur Anshori, p. hlm. 30.

26 'Tim Penyusun Undang-Undang Republik Indonesia Tentang Undang-Undang Perkawinan Nomor 1 Tahun 1974 Dan Kompilasi Hukum Islam, (Yogyakarta: Pustaka Yustisia,2008), 50 . 
baligh, berakal, melihat dan mendengar, serta mengerti (paham) akan maksud akad nikah. Namun menurut golongan Imam Hanafi dan Imam Hambali, boleh juga saksi itu satu orang laki-laki dan dua orang perempuan.

Syarat-syarat perkwinan juga diatur pada UU No. 1 tahun 1974 tentang Perkawinan pasal 6 yang berisikan sebagai berikut:54

a) Perkawinan didasarkan atas persetujuan kedua calon mempelai.

b) Untuk melangsungkan perkawinan bagi seseorang yang umurnya belum mencapai 21 tahun maka harus mendapatkan izin terlebih dahulu dari kedua orang tua.

c) Dalam hal kedua orang tua telah meninggal dunia atau tidak mampu dalam menyatakan kehendaknya, maka izin diperoleh dari wali orang yang memelihara atau keluarga yang masih memiliki hubungan darah keturunan lurus ke atas selama mereka masih hidup dan dalam keadaan menyatakan kehendaknya.

d) Perkawinan harus dilakukan sesuai dengan hukum agama.

e) Perkawinan harus dicatat menurut peraturan perundangan.

Dengan demikian yang dimaksud syarat-syarat perkawinan adalah dasar bagi sahnya perkawinan. Apabila syarat-syaratnya terpenuhi, maka perkawinan itu sah dan menimbulkan adanya segala hak dan kewajiban sebagai suami istri. 


\section{Tinjauan Akad Nikah Mempelai Tunawicara Perspektif Kompilasi Hukum Islam.}

Dari pembahasan sebelumnya, dapat dijelaskan bahwa akad adalah unsur penting dalam memulai ibadah yang diwadahi dalam sebuah pernikahan. Dengan akad nikah akan terdefinisikan secara jelas kerelaan pihak wanita untuk menyerahkan perwaliaannya kepada calon mempela pria, dan mempelai pria menerima mempelai wanita sebagai istri. Oleh karena demikian pentingnya ijab dan qobul maka dalam pelaksanaannya terdapat syarat-syarat sehingga terjadinya pelaksanaan hal tersebut tetap sejalan dengan ketentuan Kompilasi Hukum Islam, di antaranya adalah syarat dalam perwakilan qobul dengan adanya surat kuasa tertulis.

Kompilasi Hukum Islam (KHI) yang sekarang diberlakukan di lingkungan peradilan agama di Indonesia, berfungsi sebagai petunjuk dalam memeriksa, mengadili dan memutuskan perkaraperkara yang berhubungan dengan keperdataan orang-orang Islam. Dalam (KHI) Pasal 17 ayat (3) yang menyatakan "Bagi calon mempelai yang menderita tunawicara atau tunarungu persetujuan dapat dinyatakan dengan tulisan atau isyarat yang dapat dimengerti" ${ }^{27}$

Mardani dalam karyanya Hukum Keluarga Islam di Indonesia, menjelaskan bahwa syarat ijab qobul ada:28

a) Adanya pernyataan mengawinkan dari wali;

27 'Undang-Undang Perkawinan Di Indonesia, Dilengkapi Kompilasi Hukum Islam Di Indonesia, (Surabaya; Arloka), 15.', p. hlm. 345.

28 Mardani, Hukum Keluarga Islam Di Indonesia, Ed. 1, Cet. 1, ((Jakarta: Prenadamedia Group, 2016), p. hlm. 46. 
b) Adanya pernyataan penerimaan dari calon mempelai;

c) Memakai kata-kata nikah, tazwij atau terjemahkan dari kedua kata tersebut;

d) Antara ijab dan qabul jelas maksudnya;

e) Orang yang terikat dengan ijab qobul tidak sedang ihram haji atau umrah;

f) Majelis akad nikah harus dihadiri minimum empat orang, yaitu calon orang mempelai atau wakilnya, wali dari mempelai wanita dan dua orang saksi.

Dalam Kompilasi Hukum Islam yang menjelaskan Penjelasan terkait qobul terdapat dalam pasal 29 yang terdiri 3 ayat sebagai berikut:

a) Yang berhak mengucapkan qabul adalah calon mempelai pria secara

pribadi;

b) Dalam hal tertentu ucapan qobul nikah dapat diwakilkan kepada pria lain dengan ketentuan calon mempelai pria memberi kuasa yang tegas secara tertulis bahwa penerimaan wakil atas akad nikah itu adalah untuk mempelai pria;

c) Dalam hal calon mempelai wanita atau wali keberatan calon mempelai

pria diwakili, maka akad nikah tidak boleh dilangsungkan.

Menukil pendapat dari Abdul Halim dalam bukunya Politik Hukum Islam Di Indonesia Kajian Posisi Hukum Islam Dalam Politik Hukum Pemerintahan Orde Baru dan Era Reformasi, bagian latar belakang terbentuknya Kompilasi Hukum Islam, disebutkan bahwa 
dalam rangka memberi pegangan kepada hakim peradilan agama di mahkamah syar'iyah di luar Jawa dan Madura serta sebagian bekas residensi Kalimantan selatan dan timur yang dibentuk dengan Peraturan Pemerintah Nomor 45 tahun 1957 serta hakim-hakim di peradilan agama dan perapatan Qadhi yang telah dibentuk sebelum tahun 1957, biro peradilan agama menentukan 14 kitab piqh mazhab syafi'i, Antara lain: ${ }^{29}$

1) Al-bajuri;

2) Fath al-mu'in;

3) Syarqawi 'ala al-tahrir;

4) Qulyubi wa'amirah;

5) Al-mahalli;

6) Tuhfah;

7) Targih al-musytaq;

8) Fath al-wahab;

9) Al-qawanin al-syar'iyah;

10) Syamsuri li al-faraid;

11) Bughyah al-murtasidin;

12) Al-fiqh ala al-mazahib al-arba'ah;

13) Mughni mujtaj

Untuk mempelai pria yang hadir namun mengucapkan qobul dengan Bahasa isyarat, maka sesuai dengan perspektif Kompilasi Hukum Islam pasal 17 ayat (3) akadnya dianggap sah. Sedangkan ketetapan yang mewajibkan pemberian kuasa berbentuk tulisan, pada dasarnya tidak ditetapkan dalam kitab fiqh penyusun UU No 1 
Tahun 74 Tentang Perkawinan. Malah fiqh secara perbandingan secara tegas menetapkan ia boleh berbentuk kata-kata ( ) عبارةatau berbentuk tulisan. ${ }^{30}$ Hemat peneliti, ketetapan yang ditetapkan KHI ini tidak ada salahnya diundang-undangkan, mengikut kaidah almaslahah al-mursalah yang telah dijelaskan atau konsep dalam kitab Bughyah al-Mustarsyidîn mengatakan bahwa ketetapan pemerintah yang tidak diharamkan secara syariat wajib ditaati secara lahir dan batin wajib ditaati. Kalau ia bertentangan dengan syariat seperti mewajibkan sesuatu yang haram, maka cukup taat secara lahir saja. ${ }^{31}$ Namun jika dari awal dua mempelai sudah sepakat dan setuju dengan qobul mempelai pria pria yang diwakilkan tersebut, maka dianggap sah juga, mengingat dalam kitab penyusun KHI juga tidak ditemukan tentang kewajiban pemberian surat kuasa secara tertulis. Kemudian yang kedua adalah ketiadaan akibat hukum apabila tidak ada surat kuasa terbukti dengan tidak ada penjelasan di penjelas ayat. Selain itu, jika dikembalikan kepada pasal 17 ayat (3) yang berbunyi "Bagi calon mempelai yang menderita tunawicara atau tunarungu persetujuan dapat dinyatakan dengan tulisan atau isyarat yang dapat dimengerti" maka tanpa surat kuasapun tidak mengapa atau diperbolehkan. Yang jelas adalah nikahnya tetap sah, pihak KUA tidak menuntut para mempelai tunawicara untuk membuat atau menunjukan surat kuasa.

${ }^{30}$ Wahbah al-Zuhayli, Ushul Fiqh Al-Islami Wa Adillatuh, vol. 9, ((Damaskus: Dar Al-Fikr, 2004), p. hlm.6726.

${ }^{31}$ Muhammad al-Syirbînî, p. hlm. 261. 


\section{KESIMPULAN}

Praktek di lapangan saat akad nikah mempelai tunawicara yang dilaksanakan oleh wakil namun tanpa adanya surat kuasa dari mempelai tunawicara yang jelas tidak sepenuhnya salah. Karena adakalanya kedua belah pihak yakin akan tidak adanya perselisihan dalam penunjukan wakil. Para mempelai melandaskan pelaksanaan akad nikah mereka pada dorongan masyarakat, kiyai, adat setempat, dan memang kesepakatan antara kedua belah pihak.

Untuk ketetapan dalam Kompilasi Hukum Islam yang mewajibkan pemberian kuasa berbentuk tulisan, pada dasarnya tidak ditetapkan dalam kitab fiqh penyusun UU No 1 Tahun 74 Tentang Perkawinan. Malah fiqh secara tegas menetapkan ia boleh berbentuk kata-kata atau berbentuk tulisan.

\section{DAFTAR PUSTAKA}

A. Mudjab, Mahalli, Menikahlah Engkau Menjadi Kaya (Yogyakarta: Mitra Pustaka, 2008)

Abdul Halim, Politik Hukum Islam Diindonesia Kajian Posisi Hukum Islam Dalam Politik Hukum Pemerintahan Orde Baru Dan Era Reformasi, cet. Ke 1, ((TT: Badan Litbang dan Diklat Departemen Agama RI, 2008)

Abdurrahman, Kompilasi Hukum Islam Di Indonesia, ((Jakarta: Akademika Pressindo, 1992)

Abu Zaid, dan Ridha Salamah, Membangun Rumah Tangga Ideologis (Jakarta: PT. Wahyu Media Pertiwi, 2003)

Alhamdani, Risalah Hukum Perkawinan Islam, ((Jakarta: Citra Karsa Mandiri, 1995)

Al-Sayyid Hawwas, Abdul Wahab, Kunikahi Engkau Secara Islami, 
((Bandung: Pustaka Setia, 2007)

Aminuddin, Slamet Abidin dan, Fiqh Munakahat Juz 1, ((Bandung: Pustaka Setia, 1999)

Asmin SH., Status Perkawinan Antar Agama, ((Jakarta: Dian Rakyat, $\mathrm{tt})$, )

Brent D. Ruben, dan Lea P. Stewart, Komunikasi Dan Perilaku Manusia (Depok: PT Rajagrafindo Persada, 2013)

Dahlan, Idhamy, Azas Fiqh Munakahat (Surabaya: Al Ikhlas, 1984)

Ghofur Anshori, Abdul, Hukum Perkawinan Islam, ((Yogyakarta: UII Press Yogyakarta, 2011)

H. Said Al Hamdani, Hukum Perkawinan Islam, ((Jakarta: Pustaka Amani, 2002)

M. Quraish Shihab, Pengantin Al-Qur'an, ((Jakarta: Lentera Hati, 2007)

Mardani, Hukum Keluarga Islam Di Indonesia, Ed. 1, Cet. 1, ((Jakarta: Prenadamedia Group, 2016)

Muhammad al-Syirbînî, al-Khathîb, Mughnî Al-Muhtâj, vol. 4, (Beirut: Dâr al-Kutub al- 'Ilmiyyah, t.t)

Muhammad, Shahrur, Metodologi Fiqh Islam Kontemporer, Cet V, ((Yogyakarta: Elsa Press, 2008)

Rahmat, Hakim, Hukum Perkawinan Islam (Bandung: Pustaka Setia, 2000)

Supiana, dan M. Karman, Materi Pendidikan Agama Islam, cet. Ke-3 (Bandung: Remaja Rosdakarya, 2004)

Tihami, dan Sohari Sahrani, Fikih Munakahat: Kajian Fikih Nikah Lengkap (Jakarta: Rajawali, 2010)

Tim, Disbintalad, Alquan Terjemah Indonesia, Cet. Ke-22 (Jakarta 
Timur: Suara Agung, 2008)

'Tim Penyusun Undang-Undang Republik Indonesia Tentang Undang-Undang Perkawinan Nomor 1 Tahun 1974 Dan Kompilasi Hukum Islam, (Yogyakarta: Pustaka Yustisia,2008), 50'

'Undang-Undang Perkawinan Di Indonesia, Dilengkapi Kompilasi Hukum Islam Di Indonesia, (Surabaya; Arloka), 15.'

Wahbah al-Zuhayli, Ushul Fiqh Al-Islami Wa Adillatuh, vol. 9, ((Damaskus: Dar Al-Fikr, 2004) 